BMJ Paediatrics Open

\title{
Ensuring migrants' right to health? Case of undocumented children in Israel
}

Dana Moss (D , ${ }^{1}$ Zoe Gutzeit, ${ }^{2}$ Ranit Mishori, ${ }^{3}$ Nadav Davidovitch, ${ }^{4,5}$ Dani Filc ${ }^{6}$

To cite: Moss D, Gutzeit Z, Mishori R, et al. Ensuring migrants' right to health? Case of undocumented children in Israel. BMJ Paediatrics Open 2019;3:e000490. doi:10.1136/ bmjpo-2019-000490

Received 23 May 2019 Revised 12 November 2019 Accepted 16 November 2019

Check for updates

C Author(s) (or their employer(s)) 2019. Re-use permitted under CC BY-NC. No commercial re-use. See rights and permissions. Published by BMJ.

${ }^{1}$ International Advocacy Coordinator, Physicians for Human Rights Israel, Tel AvivJaffa, Israel

${ }^{2}$ Migrants Department and Open Clinic, Physicians for Human Rights Israel, Tel Aviv-Jaffa, UK ${ }^{3}$ Family Medicine, Global Health Initiatives, Georgetown University School of Medicine, Washington, District of Columbia, USA

${ }^{4}$ School of Public Health Health Systems Management, BenGurion University of the Negev, Beer-Sheva, Israel ${ }^{5}$ Physicians for Human Rights Israel Ethics Committee, Tel Aviv-Jaffa, Israel

${ }^{6}$ Physicians for Human Rights Israel, Tel Aviv, Israel

Correspondence to Dana Moss; dana@phr.org.il

\section{ABSTRACT}

After 18 years of providing government-subsidised medical insurance for children of undocumented migrants, the Israeli Ministry of Health (MOH) decided in 2018 to abruptly reverse its policy. Many children will have access to medical care only in cases of emergency. The policy change is set to potentially impact several thousands of children currently living or born in Israel. The non-profit, humanitarian sector is already seeing the impact on undocumented migrant children, with dozens of families reaching out to Physicians for Human Rights Israel to seek help accessing care for their children. These policy changes seem to be politically motivated, aiming to exclude undocumented communities from the public healthcare system as part of a general strategy of encouraging them to leave Israel. Such actions are antithetical to public health, human rights and medical ethics considerations. The Israeli Medical Association is beginning to challenge the stance of the $\mathrm{MOH}$. To conform to international guidelines-both legal and medical — government ministries and relevant official bodies must follow the advice of the medical community to ensure respect for the right to health.

\section{BACKGROUND}

With the recent rise in global migration and displacement, the medical community and policy makers are tasked with an everpressing challenge to address health issues associated with migrant communities.

Israel is home to an estimated 250000 migrants, primarily from Africa and Eastern Europe, East Asia, India and South America. Some have arrived fleeing violence or human rights violations; some are migrant workers; and others are individuals who have overstayed their tourist visas. ${ }^{1}$ We use the term migrants in its most inclusive sense to refer to all those living in Israel without legal residency and/or the possibility of securing residency. This includes asylum seekers who have not been recognised as refugees, displaced individuals, migrant workers and undocumented migrants, as outlined in table 1 . In this paper, we will focus on undocumented migrants, although individuals in all of the aforementioned communities are highly unlikely to receive legal residence status-with its' myriad health benefits-due to Israel's exclusive migration policies.

In addition to these 250000 migrants, there are, according to unofficial Ministry of Health $(\mathrm{MOH})$ sources, 10000 children of migrants. Of these, roughly 2000 are children of migrant workers and of undocumented migrants, and over 7000 are children of asylum seekers from Eritrea and Sudan (Population and Immigration Authority letter to Physicians for Human Rights Israel, July 2019). The latter African communities are protected against expulsion to their country of origin, despite nonrecognition as refugees.

\section{PALESTINIAN COMMUNITIES}

Among the 250000 migrants are an estimated 20000 Palestinians who reside in Israel for long periods of time, without being eligible for legal resident status. The case of Palestinians is a unique one, as a result of more than 50 years of occupation and the 1993 Oslo Agreement. Palestinian citizens of Israel and Palestinian legal residents (the latter being primarily Palestinians living in East Jerusalem) are eligible for full coverage by the National Health Insurance Law (NHIL). However, until 2016, Palestinians from the West Bank who married Israeli citizens or legal residents of Israel and obtained stay permits for family reunification were not eligible for legal residency and therefore coverage through the NHIL. In 2016, following a Supreme Court petition byPHRI and the Association for Civil Rights in Israel, the NHIL was also extended to them, despite the absence of legal residency. ${ }^{2}$ Palestinians living in the West Bank and Gaza are provided with health services partially subsidised by the Palestinian Authority. Palestinians who live in Israel without legal permits or those who receive special permits are not eligible for healthcare services.

\section{ACCESS TO HEALTHCARE}

Israel provides universal health coverage only to its legal residents, as defined in the Bituah Leumi law, which includes a variety of criteria. 
Table 1 Terminology and definitions

Migrant

Umbrella term for those who move away from their country of origin for a variety of reasons. This term is not legally defined. Certain types of migrants are legally defined and may legally reside in Israel despite not being legal residents, such as work migrants with valid work visas. ${ }^{3}$

$\begin{array}{ll}\text { Asylum seekers } & \text { Legal term for those fleeing their country and applying for international protection in another } \\ \text { country who have not yet been determined as refugees. However, in Israel, due to a dysfunctional } \\ \text { asylum system that did not allow many to even submit RSD applications, the term asylum seekers } \\ \text { is used by PHRI more broadly to refer to those claiming to flee from persecution, even if they did } \\ \text { not submit an actual individual asylum request. In our paper, this term refers mainly to African } \\ \text { asylum seekers, primarily from Eritrea and Sudan, who receive group protection against expulsion } \\ \text { to their countries of origin. Nevertheless, they are not granted refugee status; less than 1\% of } \\ \text { requests for asylum in Israel of Eritreans and Sudanese have been approved, compared with } \\ 71.5 \% \text { of Eritreans worldwide and } 63 \% \text { of Sudanese, as per UNHCR figures. }\end{array}$

PHRI, Physicians for Human Rights Israel; RSD, Refugee Status Determination; UNHCR, United Nations High Commissioner for Refugees.

The aforementioned communities of the 250000 are excluded from the scope of that law and are therefore barred from receiving national health insurance. In the past 25 years, at the same time that it established its universal health coverage for legal residents through the NHIL, Israel has failed to provide a comprehensive and systemic response to the health challenges posed by diverse migrant populations. Instead, it has transferred responsibility for their health to the private sector. This has left many with limited and fragmented access to appropriate medical care, including chronic care management and preventive care. Until recently, the exception to this has been the healthcare made available to minors (those under 18 years). Here the Israeli model of universal health coverage had been partially adopted and applied regardless of the legal status of their parents.

In 2018, the MOH, with the backing of other ministries, reversed its policy and now excludes some groups of minors from this insurance programme. Those excluded include children of undocumented migrant workers, of tourists whose visa has ended and of asylum seekers whose request for asylum has been denied, even in cases where they have appealed that decision. Children of asylum seekers that come from Eritrea and Sudan-the largest group of asylum seekers-are unaffected due to their group protection from deportation. Many of the children affected are born in Israel and attend Israeli schools. No hard figures are available regarding the specific number of undocumented minors affected by this decision. The reasons behind this reversal are unclear but may indicate an alarming trend where decisions on health policies are influenced by political factors that are, and ought to remain, separate from medical practice, public health, human rights and ethics considerations.

\section{ISRAEL'S MIXED RESPONSE TO THE HEALTH OF MIGRANTS}

Since coming into effect in 1995, Israel's NHIL has been applied only to Israel's legal residents. All migrants, including those with valid stay and/or work visas as well as asylum seekers, are ineligible for coverage under public healthcare programmes. ${ }^{3}$ The $y$ are forced to rely on private insurance policies, which exclude preexisting conditions, mental healthcare and rehabilitation services and which terminate once the client has become unable to work due to illness or injury. ${ }^{4}$ As adequate healthcare services are limited, many migrants are forced to rely on the Patient's Right Law (PRL), which grants urgent medical treatment to anyone with immediate life-threatening medical emergencies. ${ }^{5}$ Once their health condition is stabilised, they are discharged from the hospital without proper aftercare and with no ability to access routine primary care. Consequently, migrants often have to turn to ad hoc community-based care offered by local non-governmental organisations (NGOs) for medical assistance and specialised care. 
That the NHIL excludes all those who are not legal residents, leaving them only able to access emergency treatment, has been criticised by public health activists as unethical and in contravention of good public health practices, human rights, medical ethics and even economic considerations. Meanwhile, the over-reliance on emergency care via the PRL, coupled with the availability of private insurance options, has enabled the $\mathrm{MOH}$ to shirk its responsibility for this population, occasionally even using the aforementioned law as a justification for failing to formulate a comprehensive health policy for this community (MOH's letter to Member of Knesset Karin Elharar, 2016).

\section{FRAGMENTED, COMMUNITY-BASED CARE}

Over the past 10 years, the entry of some 60000 African asylum seekers-primarily from Eritrea and $\operatorname{Sudan}^{6}$ and the constant advocacy efforts of NGOs have led to a gradual change in the MOH's approach, which began offering partial responses aimed only at this subgroup of African asylum seekers. These responses have been far from sufficient, still leaving many without appropriate healthcare. ${ }^{7}$ Organisations such as PHRI-an Israeli human rights organisation focusing on the right to health-have tried to respond to some of the needs of migrants, including asylum seekers, undocumented migrants, displaced populations and others. ${ }^{8}$ PHRI's Open Clinic has roughly 5000 patient visits per year, handling a variety of medical conditions ranging from the common cold to heart disease and cancer, though as a volunteer-run clinic, it is unable to respond to the evergrowing needs of these populations.

\section{GOVERNMENT-PROVIDED SERVICES}

The MOH has funded two clinics to explicitly assist this population. The Terem refugee clinic, funded since 2013, offers emergency healthcare services. In 2014, the Gesher Clinic for Mental Healthcare was opened. In addition, the $\mathrm{MOH}$ also funds the Levinsky Community Clinic, which treats sexually transmitted infections and offers services to everyone. The Terem and Gesher Clinics are underfunded, understaffed and limited geographically. ${ }^{9}$ The Terem Clinic, according to $\mathrm{MOH}$ documentation, had 36389 patient files in 2015, while the Gesher Clinic, as of 2016 has treated only 610 patients (letter from $\mathrm{MOH}$ to Member of Knesset Karin Elharar, Chair of the State Comptroller's Committee, 2016). The Terem Clinic has a budget of approximately 4 million Israeli new shekel (\$1 million) per year to deal with these patients, while the Gesher Clinic has a budget of 840000 Israeli new shekel (less than \$250000). ${ }^{10}$ In September 2019, the Gesher Clinic closed and its services were transferred to a new service provider, the Ruth Clinic, with approximately the same budget.

Other clinical services provided by the government include tuberculosis treatment, which is fully funded by the MOH and the Israel Lung association, and HIV treatment in the Israeli AIDS Centres for migrants who have no access to private insurance either through their employers or privately purchased. ${ }^{11}$ In both of these cases, public health considerations led to the inclusion and integration of affected patients into the Israeli public health system.

\section{CHILDREN}

Vaccines are provided by the government, through 'Tipat Chalav' (drop of milk) services for children. The provision of government-subsidised medical insurance to children in 2001 provided an almost identical set of services as provided by the NHIL. The agreement with an Israeli health fund (named Meuhedet) to provide these services followed advocacy campaigns by physicians, public health activists and progressive politicians. Meuhedet became the only public insurer for migrant minors. As of 2015, for 120 shekels a month per child (\$30) - a cost born by the families-these children received medical coverage almost identical to that of Israeli children, regardless of their parents' legal status. ${ }^{7}$

This insurance programme is not without flaws: in contrast to the NHIL, enrolment, as well as continued medical treatment, depends on parental choice and ongoing payment. Imposing this responsibility on migrant parents specifically is problematic, given their lack of financial stability. Another problem with the government-subsidised insurance offered through the Meuhedet Health Fund is the relative lack of culturally and linguistically appropriate services. Eighteen years after its introduction-with (as of May 2018) 8110 minors enrolled-the programme was deemed a success, with an increase in the number of minors enrolled over the years. ${ }^{12} \mathrm{MOH}$ representatives even mentioned it as a potential model to expand services to adult migrants. ${ }^{13}$

\section{CHANGE IN INTERNAL POLICIES}

As of September 2018, the MOH began to deny specifically children of undocumented migrants access to this insurance programme. This was not announced publicly but only became apparent once PHRI began to receive requests for assistance from families of undocumented migrants who tried to register for medical insurance but were denied by the MOH for not having valid visas. Through the individual requests of these families, it was discovered that both newborns and children who were born and raised in Israel and were previously insured under the Meuhedet Agreement, but whose parents interrupted payment, could no longer register and reregister, respectively. As a result, these children will now only be able to access medical treatment in case of emergency.

There are no real alternatives to the Meuhedet health insurance programme for covering the ongoing health needs of these children. The only possible private insurance policy available to these children is a 'tourist' policy, 


\begin{tabular}{ll}
\hline Table 2 & Children's Health and International Law \\
\hline CRC & $\begin{array}{l}\text { Convention on the Rights of the Child, which } \\
\text { elaborates on the rights of children and which } \\
\text { Israel has ratified. }\end{array}$ \\
CESCR & $\begin{array}{l}\text { Convention on Economic, Social and Cultural } \\
\text { Rights. The right to health is enshrined in article } \\
\text { 12. Israel has ratified the Convention. }{ }^{35}\end{array}$ \\
NHIL & $\begin{array}{l}\text { The National Health Insurance Law, 1995, entitles } \\
\text { legal residents to health insurance. }\end{array}$ \\
PRL & $\begin{array}{l}\text { The Patient's Rights Law stipulates that in a } \\
\text { medical emergency, a person is entitled to receive } \\
\text { emergency medical care unconditionally. }{ }^{37}\end{array}$ \\
\hline
\end{tabular}

which excludes child development services and care of pre-existing conditions, rehabilitation or mental health. It is also subject to frequent renewals, which risks continuity of coverage and is unaffordable to many in the community. The recent change in regulations, depriving undocumented migrant children of health coverage, compounds the other social determinants of health, including poverty, fear of deportation and poor housing, all of which negatively affect health. ${ }^{14}$

Over 20 families have already reached out to PHRI since September 2018 to request assistance. Hospitals, too, have reached out to PHRI, including neonatal intensive care units, regarding newborns who were about to be discharged and were in need of follow-up treatment and management but who were not considered to be an 'emergency'.

\section{PHRI RESPONSE}

Beyond appealing individual cases, PHRI has written to the MOH to request that it reverse its decision, has engaged in public advocacy and has initiated media coverage of this situation in an effort to prompt the $\mathrm{MOH}$ to make its decision public. An appeal has also been submitted to the Israeli Supreme Court, but the hearing date will only be in December 2019, over a year since the change in policy. ${ }^{12}$

The Israeli MOH's decision is in clear violation of several international conventions (table 2). The Convention on the Rights of the Child, which Israel ratified, was the main driver behind the Meuhedet Agreement and was even cited as such by the MOH. ${ }^{15}{ }^{16}$ The Convention notes that 'States Parties recognize the right of the child to the enjoyment of the highest attainable standard of health and to facilities for the treatment of illness and rehabilitation of health. States Parties shall strive to ensure that no child is deprived of his or her right of access to such health care services' (article 24). This, as per article 2.1, applies to 'without discrimination' to all children within the state parties' jurisdiction.

The Convention on Economic, Social and Cultural Rights, which Israel has also ratified, likewise recognises 'the right of everyone to the enjoyment of the highest attainable standard of physical and mental health' (article
12) and applies regardless of civil status. ${ }^{17}$ Both General Comment 6 of the Committee on the Rights of the Child and the most recent draft General Comment on the Rights of Migrant Children likewise emphasise the principles of non-discrimination and best interest of the child. ${ }^{18}$ A recent decision by the Human Rights Committee in Toussaint versus Canada required that undocumented migrants have access to essential healthcare to prevent a reasonably foreseeable risk that can result in loss of life and that the state's burden had not been satisfied by the existence of emergency healthcare services. ${ }^{19}$ Indeed, in the Committee's recent review of Israel, the Committee noted its concern regarding the withdrawal of the application of the Meuhedet Agreement to these children and called on Israel in the Concluding Observations to 'ensure that all children, regardless of their legal status, have access to healthcare services at all times'. ${ }^{20}$

Israel is well aware of these international legal frameworks. For the 18 years that the Agreement with the Meuhedet Health Fund existed, the $\mathrm{MOH}$ and the Israeli government touted the Agreement's achievements in international meetings and Israeli Parliament debates. ${ }^{21}$

Multiple international medical organisations' policies regarding children's health echo international human rights law. The World Medical Association (WMA) of which the Israeli Medical Association (IMA) is a member-passed a resolution on "Access of Women and Children to Healthcare and the Role of Women in the Medical Profession". This Resolution notes the responsibility of constituent members to "categorically condemn violations of the basic human rights of women and children" and "insist on the rights of women and children to full and adequate medical care". ${ }^{22}$ The WMA's Ottawa Declaration on Child Health notes in its preamble that "Physicians therefore join with parents, and with world leaders to advocate for healthy children" and stipulates that "The best interests of the child shall be the primary consideration in the provision of healthcare". ${ }^{23}$

\section{COMPARISON WITH OTHER COUNTRIES}

Israel is among many countries worldwide choosing to ignore the health service needs of undocumented immigrants, migrant workers, asylum seekers and their children. Very few countries, even those with universal health coverage, have special entitlements for these populations. Among those in Europe, in Norway, children have access to services beyond basic emergency care. ${ }^{24}$ In a few countries (France, Italy, Portugal and Spain), migrant children are entitled to the same healthcare and coverage as citizens, regardless of their legal status. ${ }^{24}{ }^{25}$ In Belgium and Sweden asylum seekers and irregular non-EU migrants are eligible for "equal care" as the countries' nationals. Limited entitlements exist in twelve European countries, with Germany having one of the "most restrictive healthcare policy for migrant children". ${ }^{24}{ }^{25}$ Healthcare entitlements in Australia are highly complex and depend on the type of migration (permanent, temporary, asylum 
seeker), visa type and status. Asylum seekers' coverage specifically varies by living circumstances, (immigration detention, community, etc.) or by their means of entry (boat, airplane) and period of entry into the country. For children in the category of 'temporary residents' health insurance coverage and service entitlements vary depending on the child's visa status, family's ability to pay and country of origin. ${ }^{26}$

One of the most progressive and inclusive policies for migrant health coverage globally are enacted in Thailand, where health services are guaranteed to migrant children regardless of their legal status. In reality, however, not all eligible families and children use the services due to a variety of barriers. ${ }^{27} 28$

Finally, in the US, which does not have universal health coverage, migrant children's coverage options vary by their immigration status. In general, undocumented immigrants (including asylum seekers) cannot purchase health insurance plans as part of the Affordable Care Act (ACA), they are barred from coverage under Medicare and Medicaid, and undocumented children do not qualify for the Children's Health Insurance Programme, known as CHIP. Some states, however, do provide coverage for some undocumented immigrant children and pregnant women. ${ }^{29}{ }^{30}$ Children who are born in the US to undocumented immigrants are eligible for Medicaid and CHIP coverage. There are, however, efforts underway from the current US administration to strip or restrict eligibility for coverage of those dependent on public benefits, such as health insurance. A recent study found that if the proposal were to be enacted many migrant children, deemed "public charges", will have difficulty accessing government health benefits, which may result in millions of children becoming uninsured. ${ }^{31}$

\section{RESPONSE OF MEDICAL ORGANISATIONS}

To combat the deviation between international law, medical ethics and Israeli policy, PHRI has appealed to the IMA, Israeli Pediatric Association, which is under the umbrella of the IMA, and several public hospitals requesting their assistance in overturning the new ruling. The IMA, after being made aware of the impact on this community, made a decision to join PHRI's legal petition, due to be heard in the High Court of Justice at the end of 2019. This decision follows the IMA's 2003 position paper, which noted that 'the presence in Israel of hundreds of thousands of migrant workers requires the State institutions to relate to the basic rights of these workers, including their well-being, health and medical situation'. ${ }^{32}$ Thus far, the MOH has chosen to adhere to its policy nonetheless. This is not unique to Israel but is unfortunately a global phenomenon, with, for example, very vocal statements by the American Academy of Pediatrics and others on child separation, which have been insufficiently respected by the US authorities, which have reportedly continued the practice. In this specific case, however, it is the $\mathrm{MOH}$, the body responsible for "policy on matters of health and medical services' that decided to deny medical services, rendering the guidance of right to health and/or medical organisation even more relevant.

All migrants currently residing in Israel-regardless of their legal status-have a right to healthcare. Children, especially migrant children, are a vulnerable population. The impact of the new regulations is clear and will continue to increase, as children continue to be born to families of undocumented migrants. Aside from the impact on families who have already reached out to PHRI, there are families that we are not yet aware of whose children have unidentified conditions and who remain unseen by any doctor, but who may soon develop medical emergencies.

To adhere to a policy that respects medical ethics and the right to health, the $\mathrm{MOH}$ would well consider to be guided by the stance of organisations such as the IMA and PHRI. A similar stance must be taken by health authorities around the world where migrant children likewise receive little entitlement with respect to healthcare.

In the interest of public health best practices, human rights and medical ethics, a clear separation must be made between the available legal tools that can be used to address illegal migration and the need to protect all children who live in Israel and elsewhere in the world. The government must reinstate health insurance coverage to children of migrants at once, regardless of their parents' status.

Contributors DM and ZG conceived of and planned the paper, carried out the analysis of the results and wrote the manuscript, with input from RM. All authors reviewed and edited the manuscript.

Funding The authors have not declared a specific grant for this research from any funding agency in the public, commercial or not-for-profit sectors.

Competing interests None declared.

Patient consent for publication Not required.

Provenance and peer review Commissioned; externally peer reviewed.

Data availability statement There are no data in this work.

Open access This is an open access article distributed in accordance with the Creative Commons Attribution Non Commercial (CC BY-NC 4.0) license, which permits others to distribute, remix, adapt, build upon this work non-commercially, and license their derivative works on different terms, provided the original work is properly cited, appropriate credit is given, any changes made indicated, and the use is non-commercial. See: http://creativecommons.org/licenses/by-nc/4.0/.

ORCID iD

Dana Moss http://orcid.org/0000-0002-0195-8160

\section{REFERENCES}

1 Data on Foreigners in Israel, Division of Policy and Strategic Planning of the Population and Immigration Authority. First quarter of 2019. Available: https://www.gov.il/BlobFolder/generalpage/foreign workers_stats/he/577455-ZARIM-2019.pdf [Accessed May 2019].

2 Association of Civil Rights in Israel. Giving social rights to those hurt by the citizenship law, 2015. Available: https://law.acri.org.il/he/2166

3 National Health Insurance Law. 1994, Article 3 (a) states "every resident shall be entitled to health insurance", 1994. Available: https://www.nevo.co.il/law_html/Law01/036_001.htm\#Seif3 [Accessed Mar 2019].

4 Migrants migrant workers order, 2001. Available: https://www.nevo. co.il/law_html/Law01/P178_007.htm [Accessed Feb 2019]. 
5 The Patient's Rights Law, 1996, Section C. Article 3(b). Available: https://www.nevo.co.il/law_html/Law01/133_001.htm [Accessed Mar 2019].

6 Data on foreigners in Israel, division of policy and strategic planning of the population and immigration authority. final edition for 2018. Available: https://www.gov.il/BlobFolder/generalpage/foreign workers_stats/he/foreigners_summary_2018.pdf [Accessed May 2019].

7 Shamir E, Gutzeit Z N. Painful exclusion: the costs of denying asylum seekers access to healthcare services in Israel, and a proposal for a remedy, 2017. Available: http://cdn2.phr.org.il/wpcontent/uploads/2017/11/painful-exclusion-report-english-phri2017.pdf [Accessed Apr 2019].

8 The authors are members of PHRI.

9 Shamir E, Gutzeit Z, P. 21

10 Shamir E, Gutzeit Z, P. 30

11 Moran EB, Katz MA, Ari O-B, et al. For what illnesses do asylum seekers and Undocumented migrant workers in Israel seek healthcare? an analysis of medical visits at a large urgent care clinic for the uninsured in TEL Aviv. Int J Environ Res Public Health;16:252.

12 Yaron L. Israel cuts off medical coverage for children of parents with expired visas. Haaretz, 2018. Available: https://www.haaretz. com/israel-news/.premium-health-ministry-decision-could-leavethousands-of-children-without-health-insurance-1.6544456 [Accessed 9 Oct 2018].

13 Labour. Welfare and health Committee meeting 2018.

14 Fleishman Y, Willen S, Davidovich N. Migration as a social determinant of health for irregular migrants: Israel as case study. social science and medicine 2015.

15 UN General Assembly. Convention on the rights of the child, 20 November 1989, United nations, Treaty series. Available: https:// www.refworld.org/docid/3ae6b38fo.html [Accessed Aug 2019].

16 Circular of the director general, Ministry of health, March 15, 2016. Available: https://www.health.gov.il/hozer/mk05 2016.pdf [Accessed Apr 2019].

17 UN Committee on Economic, Social and Cultural Rights (CESCR). General Comment No. 14: the right to the highest attainable standard of health (art. 12 of the covenant), art. 18, 11 August 2000, E/C.12/2000/4. Available: https://www.refworld.org/docid/ 4538838d0.html [Accessed 20 Feb 2019].

18 UN Committee on the protection of the rights of all migrant workers and members of their families, joint Comment No. 3 and Committee on the rights of the child, joint Comment No. 21 in the context of international migration. draft, 2017. Available: https://tbinternet. ohchr.org/Treaties/CMW/Shared\%20Documents/1_Global/INT CMW_INF_8219_E.pdf [Accessed Apr 2019].

19 Toussaint V. Canada [2018], CCPR/C/123/D/2348/2014 2018.

20 UN Committee on Economic, Social and Cultural Rights (CESCR). Un Committee on economic, social and cultural rights: state Party report: Israel, 14 January 2019, E/C.12/ISR/CO/4. Available: https:// tbinternet.ohchr.org/_layouts/15/treatybodyexternal/Download.aspx? symbolno=E\%2fC.12\%2flSR\%2fCO\%2f4\&Lang=en [Accessed Oct 2019].

21 UN Committee on Economic, Social and Cultural Rights (CESCR). Un Committee on economic, social and cultural rights: state Party report: Israel, 14 January 2019, E/C.12/ISR/4. Available: https:// tbinternet.ohchr.org/_layouts/treatybodyexternal/Download.aspx? symbolno=E\%2fC.12\%2fISR\%2f4\&Lang=en [Accessed Feb 2019].

22 World Medical Association. Resolution on access of women and children to healthcare and the role of women in the medical profession, 1997. Available: https://www.wma.net/policies-post/ wma-resolution-on-access-of-women-and-children-to-health-careand-the-role-of-women-in-the-medical-profession/ [Accessed Feb 2019].

23 World Medical Association. Declaration of Ottawa on child health, 1998. Available: https://www.wma.net/policies-post/wmadeclaration-of-ottawa-on-child-health/ [Accessed Feb 2019].

24 Stubbe Østergaard L, Norredam M, Mock-Munoz de Luna C, et al. Restricted health care entitlements for child migrants in Europe and Australia. Eur J Public Health 2017;27:869-73.

25 Hjern A, Østergaard LS, Norredam M, et al. Health policies for migrant children in Europe and Australia. The Lancet 2017;389:249.

26 Little R, Goldfeld S. Entitlements to healthcare for migrant children in Australia and relationship to migration status. Available: http://www. childhealthservicemodels.eu/wp-content/uploads/2015/09/MOCHA FINAL_REPORT_18_8_2016-2.pdf [Accessed 5 Jul 2019].

27 Onarheim KH, Melberg A, Meier BM, et al. Towards universal health coverage: including undocumented migrants. BMJ Glob Health 2018;3:e001031.

28 Thailand Migration Report 2019 [EN/TH] - Thailand. ReliefWeb. Available: https://reliefweb.int/report/thailand/thailand-migrationreport-2019-enth [Accessed 5 Jul 2019].

29 Adams RJ. Undocumented kids get health care in six states, D.C center for health journalism. Available: https://www.centerforhealth ournalism.org/fellowships/projects/undocumented-kids-get-healthcare-six-states-dc [Accessed 5 Jul 2019].

30 Health Insurance. How immigrants are getting health coverage. Available: https://www.healthinsurance.org/obamacare/howimmigrants-are-getting-health-coverage/ [Accessed 4 Jul 2019].

31 Zallman L, Finnegan KE, Himmelstein DU, et al. Implications of changing public charge immigration rules for children who need medical care. JAMA Pediatr 2019:e191744.

32 Israeli Medical Association. The health of labour immigrants, position paper, 2003. Available: https://www.ima.org.il/ENG/ViewContent. aspx?Categoryld=4499 [Accessed Feb 2019].

33 International Organization for Migration. Who is a migrant. Available: https://www.iom.int/who-is-a-migrant [Accessed Jul 2019].

34 Guthmann A, Peleg R. Guide for integrating asylum seekers, Anat Guthmann, RON Peleg, 2019. Available: https://hotline.org.il/wpcontent/uploads/2019/03/Eng-Web-Municipalities-Guide-2018.pdf [Accessed Aug 2019].

35 UN General Assembly. International covenant on economic, social and cultural rights, 16 December 1966, United nations, Treaty series, 2019. Available: https://www.refworld.org/docid/3ae6b36c0.html [Accessed 8 Aug 2019].

36 National health insurance law, 1994. Available: https://www.nevo.co. il/law_html/Law01/036_001.htm\#Seif3 [Accessed Mar 2019].

37 Section C Article 3(b), Patients Rights Law 1996. 